\title{
WHITMAN, CHRIST, AND THE CRYSTAL PALACE POLICE: A MANUSCRIPT SOURCE RESTORED
}

\author{
Paul Benton
}

WHAT PRECIPITATED the first Leaves of Grass? What enabled a well-worn journalist and under-employed house builder to emerge so suddenly as such a powerful and revolutionary poet? In his recent answer to that perennial question, Ed Cutler has proposed that New York City's 1853 Crystal Palace Exhibition provided a model and impetus for the spectacular display of the 1855 Leaves. ${ }^{1}$ To link Whitman in some way to the Crystal Palace, Cutler has resurrected a long-forgotten and most curious story: that the police put Whitman under close surveillance because he spent such a suspiciously long time admiring one of the Exhibition's most famous attractions, Bertel Thorwaldsen's colossal statues of "Christ and His Apostles." As evidence for Cutler's argument, however, this old tale has two weaknesses. First, it sounds apocryphal, and since Cutler's only source is the undocumented version in Emory Holloway's 1926 biography, he is forced to add a cautious conditional"if Holloway's anecdote can be believed." 3 Second, and more fundamentally, the story has nothing to do with the Crystal Palace's celebration of modern technology and hence gives no direct support to Cutler's claim that Leaves emulated its display of "global industrial democracy."

In the Beinecke Library at Yale, however, there are a couple of almost illegible pages of manuscript that establish the authority of the story about Whitman, Christ, and the Crystal Palace police, at least in the sense that Whitman himself must have been its source. ${ }^{5}$ Moreover, once recovered and read closely in that original or near original version, the story turns out to have two unexpected values. First, it opens up a part of Whitman's life that his biographers have neglected-how he got along with the New York City police. More importantly, the story suggests quite a different origin for the first Leaves: not in the democratically eclectic displays of American and European art and industry, but in the mysteriously sacred space almost accidentally opened up by Thorwaldsen's huge tableau, a virtual space defined by the figures of a group of ordinary men drawn together around the body of their resurrected Lord.

I.

In writing his 1926 version of the Crystal Palace story, Emory Holloway apparently relied on a long 1866 "Memoranda" written by 
Whitman's close friend William D. O'Connor-or he may have used a now-lost Whitman holograph that O'Connor had copied or paraphrased. We know Holloway had access to that "Memoranda," because a decade later he quoted from other parts of it in New York Dissected, his 1936 collection of some Whitman journalism. ${ }^{6}$ The possibility that Holloway also had Whitman's holograph version of the story is suggested by his reference elsewhere in New York Dissected to "his own draft [i.e. Whitman's] of a memorandum sent by ... O'Connor to . . Moncure D. Conway."7 That possibility is strengthened substantially by the striking fact that the Crystal Palace story is almost illegible in the O'Connor "Memoranda" itself, having been cancelled with thick strokes of ink that obscure most of the script (see the photograph on the back cover). Unless Holloway's eyes were much sharper than mine, he would have had considerable difficulty deciphering the Crystal Palace story under O'Connor's heavy cancellation. And if Holloway did not make that effort with the "Memoranda" text, he must have had some other version, presumably Whitman's own draft, on which to rely. That suggests that in recovering the "Memoranda" text that O'Connor obliterated, we may be restoring a copy or paraphrase of a missing Whitman holograph. At the least, even if that Whitman draft is a phantom, ${ }^{8}$ this evidence suggests that the poet was directly responsible not only for O'Connor's version of the Crystal Palace story, but almost certainly for its cancellation as well.

Before considering motives for O'Connor (or Whitman) first writing and then suppressing the Crystal Palace story, it would be useful to compare the 1926 version on which Cutler relies with the version in the 1866 "Memoranda." In transcribing the latter I have followed O'Connor's lineation in order to make it easier to compare my readings with the photographic evidence (see Figure 1). For the sake of context I also include the immediately preceding sentence about the Egyptian Museum (the one Holloway quoted in 1936), as well as a few subsequent sentences about how the poet's "chief books have been men."

\section{Holloway, Whitman: An Interpretation in Narrative (1926), 97:}

So curious and persistent was he [Whitman] in his study of whatever specially interested him that he excited the attention of the police, who exercised particular surveillance over him. It was beyond the intelligence of a simple policeman to comprehend how a roughly dressed visitor could stand for hours before Thorwaldsen's marbles unless he were premeditating a theft. When, sometime later, Walt made the acquaintance of these same policemen, they confided to him, to his amusement, their former fears and precautions. 
2. O’Connor, "Memoranda" (1866), 4b-d: ${ }^{9}$

[4b] For years, he frequented constantly Dr Abbott's Museum

of Egyptian antiquities in New York, absorbing everything. When the World's Fair-I mean the Crystal Palace-was held in New York, he <studying every thing.> was there all the time, $\wedge$ and by his eurious and persistent study of eertain things, exeited the attention of the poliee, was speeially [observed?] indeed for some time, those simple worthies not being able to understand how a man eould stand, perhaps for the best part of a day, surveying some object without [some?] [exeited??] designs in referenee to it. There was some giant group of statuary there I think it was Thorwatelsen's and the ????? vigilanee on the part of the constabulary was [4c] exeited by Walt's devotion to it. It is beyond doubt that they had some eloudy notion, sueh as simple intelleets sometimes absurdly entertain, that he intended to steal it. Afterwards when Walt (as common with him) beeame fast friends with some of these polieemen, they frankly eonfess= ed to him their former doubts suspie ions and misgivings with regard to him and informed him how he had been "spotted" by them, especially $\leftrightarrow$ the $>$

in reference to $\wedge$ - Thorwaldsen's huge group of statuary.

But his chief books have been men. The common average peoplethe rough, the rude, the simple, the uneducated, the toilers of the earth and sea-these he has lived with, enjoyed with, sympathized with-these he has closely and [4d] lovingly perused, reading to the last word, understanding to the last shade of its meanings, the letter of their natures and their lives; .... .

Obviously Holloway made some significant changes, such as adding the image of Whitman as "roughly dressed" and reducing Whitman's relationship to the police from "fast friends" to "acquaintance." Small 
differences of that sort suggest that his narrative purpose, his sense of the larger significance of this anecdote, differed a little from O'Connor's, and hence probably from Whitman's. But just what was the original purpose of the 1866 "Memoranda" to Conway? And what light does that intent throw on O'Connor's decision-surely with Whitman's approval, perhaps at his request - to delete the Crystal Palace story from it?

II.

In the two years following the end of the Civil War-between June 1865, when Whitman was fired from his government desk job because his newly appointed boss considered Leaves scandalous, and July 1867, when William Michael Rossetti published his laudatory article in the London Chronicle-Whitman collaborated with O'Connor and the young naturalist John Burroughs in a complex and evolving effort to reinterpret his status as a poet. O'Connor's polemical pamphlet The Good Gray Poet, written in August-October 1865 and published in January 1866, was a part of that collaborative effort. Another strand was quietly emerging in numerous draft essays that Burroughs was writing on Whitman and the aesthetics of nature. Most of these rough essays remain unpublished to this day, but out of them emerged, with the help of Whitman and O'Connor, both Burroughs's substantial interpretive article published in the new Galaxy magazine (December 1866) and his Notes on Walt Whitman as Poet and Person, the first book-length study of Whitman (completed in February 1867, published that June). About the same time, Whitman himself was working through multiple drafts of a new prose preface to Leaves, transforming the 1861 version of an unpublished "Introduction" into "Inscription at the Entrance," a prose piece that eventually was reduced to the short poem that prefaced the 1867 edition (printed in August 1866).

It is impossible to compress the whole of this multi-phased and fluid collaborative project into a brief summary. ${ }^{10}$ But one important issue was the relationship between the naive and the sophisticated in Whitman: was he the voice of nature, as Burroughs believed, or the master of a new phase of culture, as O'Connor argued? The tension between these two views was especially cogent as the three friends considered how to nurture Whitman's reputation in England. On the one hand, a more earthy Whitman offered a breath of fresh air that would appeal to those caught in Tennysonian doldrums. On the other, without superior cultural credentials the English might dismiss Whitman as primitive, as a naive and folksy versifier.

This evolving issue came to a head in the spring of 1866, when Moncure Conway, a liberal American pastor in London, wrote his old acquaintance and fellow radical O'Connor, explaining that he was work- 
ing on a Whitman article for the Fortnightly Review and hinting that he might be able to use some biographical highlights. O'Connor responded by compiling the thirty-two page "Memoranda" now in the Beinecke Library at Yale, summarizing what he had heard from Whitman and copying or paraphrasing various manuscript notes that Whitman had given him, most of which he transcribed without acknowledgment. ${ }^{11}$ This was a major collaborative effort by O'Connor and Whitman, for they recognized the opportunity for a breakthrough article, knowing that Conway would be an energetic advocate. And yet they probably suspected, with good reason, that he would tend to stress the more colorful, racy side of the new American bard.

Perhaps to counter Conway's anticipated bias (and partly, I think, to stake out a certain position in the on-going culture/nature debate between O'Connor and Burroughs), the "Memoranda" emphasized Whitman's immersion in literature and the arts, especially his reading of the classics from the Bible to the German Idealists, from Dante and Shakespeare to Emerson. Lest he be mistaken for a superficial skimmer, the "Memoranda" insisted that Whitman had a deep and immediate understanding of the texts of the great masters, "as by affinity of mental structures." 12 But after the long inventory of Whitman's favorite authors, O'Connor concluded, as we saw in the transcript above, that the poet's "chief books have been men," insisting that his poems are great because he has applied his intuitive powers of deep reading to "the common average people": "these he has closely and lovingly perused, reading to the last word, understanding to the last shade of its meanings, the letter of their natures and their lives." 13

At first it must have seemed to Whitman and O'Connor that the Crystal Palace story would fit that scheme, linking an appreciation of high culture to a deep "reading" of people. On one hand the anecdote further illustrated Whitman's serious approach to the wide range of the arts offered by New York. And yet on the other it implied that the most enduring result of his contemplation of the Thorwaldsen statues was the friendship that emerged, "as common with him," between Whitman and the young men who had "spotted" him. In fact O'Connor used the story as a way of concluding this part of the "Memoranda," as a transition from his extensive cultural inventory to the briefer but emphatic claim that Whitman's greatness finally rested on his extraordinary relationships with ordinary people - "these he has lived with, enjoyed with, sympathized with." ${ }^{14}$ The "Memoranda" clearly links the fact that Whitman spent hours contemplating Thorwaldsen's statues to the fact that he became "fast friends" with the young New Yorkers who guarded them. Apparently both the aesthetically represented disciples and the physically present police were fascinating groups of men to the emerging poet. And conversely the police apparently found Whitman as fascinating as the statues they were guarding. Or to look at the same 
complex set of relationships from another angle, the "Memoranda" set up an analogy between two concentric circles of men, the police being drawn to Whitman as the disciples were drawn to Christ - though for different reasons, at least on the surface.

Why then did O'Connor, surely with Whitman's approval, decide to eliminate this rhetorically suggestive story from the material they were sending to Conway in London? Perhaps because they feared that the awkward initial situation might be more memorable than the friendly denouement, that Conway might choose to make Whitman famous as the man police suspected of plotting, quite absurdly, to steal thirteen gigantic plaster statues. That was the kind of humorous, almost (but not quite) scandalous episode a colorful writer like Conway might relish and highlight, at some cost to the more serious image that O'Connor and Whitman were trying to promote, the image of a refreshingly modern poet who nevertheless exhibited "the finest spiritual culture and an imperial delicacy of breeding." 15

So O'Connor obliterated two pages of the "Memoranda" and the Crystal Palace story was buried until Holloway somehow recovered it sixty years later. Even then no other Whitman scholar paid attention to it until Cutler noticed it again after another seventy years. ${ }^{16}$ Has that mattered? Does the story really add anything to our understanding of Whitman? The anecdote is quite brief, of course, with no explicit connection to Whitman's poetry. And yet it may be rather surprisingly useful in two dimensions, first opening up a neglected aspect of Whitman's biography-his relationship to the police-and then suggesting something about the origins of Leaves, not so much in the larger spectacle of the Crystal Palace exhibition as in the uncanny power of Thorwaldsen's religious tableau.

\section{III.}

As far as I can tell Whitman's biographers have overlooked the significance of the fact that he was supposedly "fast friends" with New York policemen. One might think that a free-spirited rover like Whitman would have been uncomfortable with men whose general function was to maintain civic order by repressing the rowdy energies of the street. And this might be especially true of New York policemen, who for years had been at the center of partisan wrangles, who were often perceived as agents of the kind of party politics that Whitman had come to abhor.

A little background may help us grasp the problem more concretely. ${ }^{17}$ In the 1840 s New York leaders had tried to improve public safety and civic order by replacing the loose system of fee-paid marshals and moonlighting watchmen with a professional force of salaried policemen. By 1853, however, the public still lacked confidence in the police, partly because many regarded them as political lackeys (appointed 
by a ward alderman whom they were expected to help re-elect), partly because they were reputed to be undisciplined, even negligent, sometimes congregating in saloons when they should have been walking their beats. Some New Yorkers argued that the police would be more diligent if they were required to wear uniforms as the London police did, making loiterers more obvious. But others insisted that wearing anything more "uniform" than a copper star (hence the slang "cops") would be "inconsistent with their notions of Republican equality." 18

The Crystal Palace police were quite distinctive, however, having been recruited and trained specifically to guard the expensive exhibits. Though sometimes criticized for knowing little about the displays they kept secure, they were widely admired for being constantly on watchexcept of course when ranks of them were drilling to music up and down the corridors, proudly carrying their night sticks and showing off their new uniforms: dark blue frock-coats and pantaloons, with glazed shoulder-belts and caps lettered "C. P. Police." Today such an image may remind us of the comic policemen of Penzance or Mack Sennett's Keystone Kops, but in mid-1853 the New York Times seriously hoped that "healthy emulation" of these well-dressed, well-drilled C. P. Police, like the ones who put Whitman under surveillance, would improve the professionalism of the police force as a whole. ${ }^{20}$ In fact that fall Mayor Westervelt ordered all New York policemen into uniform, and within months the arrest rate soared..$^{21}$

In early 1855 the new Democratic mayor, Fernando Wood, was widely applauded at first for consolidating the now-uniformed police under his own authority, freeing them from "entanglements in ward politics" as part of his effort to reform New York under a strong central executive who would both enforce the law and improve social services. ${ }^{22}$ Rather quickly, however, Mayor Wood's political opponents convinced much of the public that he had merely turned the police into the quasimilitary arm of his own political machine. When the Republicans won the state legislature in 1856, they imposed a new charter on New York City, which among other things boldly replaced Mayor Wood's "Municipal" police with a new "Metropolitan" force directed by a state commission. The Mayor resisted Albany's intervention, a resistance that climaxed in June 1857 when Wood's loyal "Municipals" confronted the state's "Metropolitans" in a brief but bloody fight on the steps of City Hall. Wood capitulated, but weeks later a Fourth of July riot broke out in the Bowery, ignited by an Irish gang called the "Dead Rabbits" and fueled by the Mayor's many supporters among the immigrant underclass. The new "Metropolitans" soon found themselves engaged in a battle on the barricaded streets, with stones pouring down from the tenement rooftops. It was an interesting moment, at least visually reminiscent of conflicts in European cities in the late 1840s. ${ }^{23}$ In that sense the New York police had come of age, evolving in little more than a 
decade from a loosely organized group of city watchmen to a "civic army."

What did Whitman think of all this? We have some indication from his "New York Dissected" articles published in Life Illustrated in the summer of 1856, a year after Mayor Wood took over the police, a year before the crisis precipitated by state intervention-the same year Whitman wrote "The Eighteenth Presidency," his exuberant condemnation of politics as usual, and published the second edition of Leaves with its letter to Emerson presenting the poet as spokesman for a new generation of independent working-class men. Toward the end of his series of upbeat urban portraits in Life Illustrated, Whitman conceded that "New York is one of the most crime-haunted and dangerous cities in Christendom." 24 But he seemed to regard the police as a redemptive factor, not as part of the problem, advising visitors to seek help "from the blue-coated and starred policeman, whom you will probably discern every square or two." 25 The police were now a well-disciplined, quasimilitary force, quite like the Crystal Palace police a couple of years earlier, and Whitman emphasized, perhaps with a hint of sarcasm, the distinctive color they added to the urban scene: "Now a little army of police, two and two, girt with clubs, a stern-faced and ready-handed race, passes by with military step detached on some duty." ${ }^{26}$ At least Whitman betrayed no sense of fear or distrust of this "little army." On the contrary, at this point the police apparently represented for him a positive side of the American political order, as when he noted that the Fourth of July parade of 1856 was "headed by two platoons of policeto indicate that, after all, the civil power is first." 27

It was just a year later, however, that the celebration of the Fourth exploded into the bloody Bowery riot-just weeks after the brief civil war between the Mayor's "Municipals" and the state's "Metropolitans." Public opinion shifted quickly, and Whitman both expressed and guided that shift, his former admiration of the police as an emblem of healthy "civil power" apparently having soured into disdain for them as instruments of a corrupt political machine. At least that is the indication of two 1857 editorials in the Brooklyn Daily Times (anonymous but widely assumed to be Whitman's), one referring to the June confrontation as "Fernando's desperate course" and the other deploring the partisanship that led to the Bowery riot. ${ }^{28}$ Neither editorial considered the deeper issues: contested sovereignty (state vs. city) and the growing alienation of poor immigrants from the "native" population. Instead the editor of this purportedly independent paper (presumably Whitman) disparaged Mayor Wood as a demagogue and his Bowery supporters as lawless rowdies, emphasizing that solid citizens should wash their hands of the underlying cause, the "tyranny of party fealty." 29 The only direct reference to the police in these editorials elided the distinction between the Mayor's "Municipals" and the state's "Metropolitans," asserting that 
"the police" in general were themselves part of the problem: "Had not the police been long ago prostituted to political uses, such a crisis as now exists could never have arisen." $" 30$

Did that political condemnation of a police force that was "long ago prostituted" color Whitman's more personal feelings about individual policemen-assuming that he was, in fact, the author of those editorials? I have found no evidence that it did. On the contrary, he seems to have regarded individual policemen not as political lackeys but as fellow members of the working class.

Whitman probably came in most frequent contact with the police as they sorted out traffic jams on Broadway or tried to restrain the energetic stage-drivers with whom he loved to ride. One 1862 notebook entry is particularly revealing about this. Though it has no direct connection with either the Crystal Palace police or the 1857 crisis, I include a full transcript here because it is quite dramatic and because when Edward Grier published it in Notebooks and Unpublished Manuscripts (1984), he did not have the original at hand:

occurred on Thursday, $\wedge<$ about sundown> April 10th [1862] / stage 436

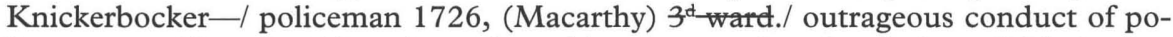
liceman-pulling the driver down from his stage, tearing the clothes off his backand then going up to the stables, and taking him off to the station house, and locking him up all night-Brought before Justice Connolly next morning, he was discharged, even on the policeman's own statement./ The Most of the Broadway squad of policemen are very well behaved to drivers, (although there are exceptions.) But new police sudtenty occasionaly [sic] detailed for some specialty occasion to Broadway are apt to be very insolent and unreasonable ${ }^{31}$

Whatever reason Whitman had for making these notes (a letter of protest? a newspaper article?), he was obviously writing from the point of view of the men with whom he rode: note that the policeman's violent action is called "outrageous," but nothing is said of the teamster's provocation. Equally obvious, however, is the fact that Whitman does not frame this episode as part of a larger pattern of police brutality or corruption. On the contrary, his concluding reference to the "Broadway squad of policemen" suggests that he liked and trusted most of the policemen he knew as regulars, that he attributed the occasional police insolence not to strong-arm politics or even racial (Irish vs. "natives") tension, but to the fact that new policemen were outsiders, unfamiliar with the other working men who also made their living along Broadway.

So it should come as no surprise that when policemen appear in Whitman's poems they are imagined as a natural part of the multifarious city work force, as men busy at their jobs establishing order in a crowd or walking a beat or clearing the way for a parade. ${ }^{32}$ Nor should we be surprised that policemen appear frequently in the long lists of acquaintances Whitman recorded in his notebooks, most of whom were 
working-class men. Among the hundreds of names on these lists, I count eighteen that Whitman specifically identified as New York or Brooklyn policemen in three notebooks from 1855-1862, and another six in two notebooks from the Washington years. ${ }^{33}$ There may have been many more.

Were any of these two dozen police originally part of the Crystal Palace force that became "fast friends" with Whitman? I have found nothing that makes that direct connection. But I have come across evidence that Whitman was close enough to one New York policemen, Elijah Tompkins, to spend a week's vacation with him and his family. Though there are entries about Officer Tompkins in three separate Whitman notebooks, no biographer has mentioned him, probably because Whitman included no information beyond addresses and the facts that Elijah enlisted in the Union army in 1862 and was arrested as a deserter in $1864 .{ }^{34}$ But recently some new information has turned up in provenance material related to a first edition of Leaves now at the College of New Jersey in Trenton, a copy given to the lyricist Oscar Hammerstein by the writer Alfred Woollacott in the mid-1950s. ${ }^{35}$ In a letter to Hammerstein, Woollacott recalled that around the time of his marriage in 1919 he had heard an interesting story from Aunt Fern Thompkins [sic], an elderly friend of his fiancée's family in Navesink, New Jersey. ${ }^{36}$ According to Aunt Fern, her older brother-a New York policeman - had been such a close friend of Whitman that the poet spent a week vacationing at the Thompkins family farm in Navesink. Though she had been just a girl back then, Fern remembered watching Whitman as he sat for hours with his bare feet up against a tree, "looking off over the hills-a-thinking and a-thinking. He was a poet you know." ${ }^{37} \mathrm{Did}$ Woollacott get his first edition Leaves from Aunt Fern Thompkins? Although his letter to Hammerstein does not say that explicitly, it is at least a possibility. And in that case it is likely that Whitman had given his book to Elijah-unless (an even more intriguing possibility) young Officer Tompkins bought a copy, which would make him one of the few working-class Americans to show an interest in the first edition of Leaves. ${ }^{38}$

So in these small ways the Crystal Palace story helps open up one aspect of Whitman's personal life - his relationship with policemen. But does the story shed any light at all on Whitman's poetry?

IV.

Ed Cutler thought that this odd little anecdote supported the general thesis of his 1998 article: that the Exhibition provided a model for Leaves of Grass, that the "poet-kosmos" was "a type of the Crystal Palace itself," that "Song of Myself" in particular emulated the form of the Exhibit in celebrating "modernity" and the new "global industrial de- 
mocracy." ${ }^{39}$ But I see nothing relevant to that view in the Thorwaldsen/ police story. On the contrary, it suggests, as does Whitman's only other extended comment on the Exhibition, that Whitman valued the Crystal Palace for its exhibits of traditional art, not for its revolutionary display of industrial democracy. ${ }^{40}$

In fact I would argue that if the Crystal Palace exhibit as a whole did help shape the form of the first Leaves, it was as a foil, not as a prototype. Unlike the 1853 Crystal Palace, the 1855 Leaves of Grass emphasized fresh air, the open road, and endless vistas - not a symmetrical beehive of closely watched rooms under a glass dome. Instead of marble statues, iron machines, and cases full of Venetian lace and American pistols, these new poems displayed the breathing, lusting, feeling, suffering body as it merged ecstatically with the soul. Even the so-called catalogs in Leaves were not inventories of metonymically representative artifacts, as Cutler claims, ${ }^{41}$ but rushing streams of brief vignettes, projecting readers out into the world, out into the lives of people being themselves in their own times and spaces. Whitman's poetry, in short, was quite unlike the Crystal Palace Exhibit, celebrating a fundamentally different species of modernity in a radically different way.

And yet the Crystal Palace story does give us a clue about the origins of Whitman's new poetry if we look more closely at Whitman's strong attraction to the Thorwaldsen statues. Whitman was not alone in being so attracted. The larger-than-life group of "Christ and His Apostles" in a quiet side gallery drew more public attention than the huge statue of Washington that occupied center stage under the soaring glass dome. It consistently drew larger crowds than Hiram Powers's notoriously titillating "Greek Slave" or the "talismanic power" of his "Eve," famous for having been hauled up from the sunken ship in which Margaret Fuller Ossoli had drowned. ${ }^{42}$ Even more distinctive was the kind of attention given to Thorwaldsen's colossal tableau. One reporter noticed that "many who look upon the group almost involuntarily uncover their heads, as they would in entering a sacred edifice, and stand silently gazing upon it, or quietly conversing in respect to its meaning. The contrast between this and other portions of the building is very striking, even to a casual observer." 43

Did Whitman find anything more, or anything different, than these reverent visitors? Cutler guesses that he did, suggesting that Whitman was drawn to the famous image of the resurrected Christ as a central instance of what he feared in the Exhibit's spectacular mode, since Thorwaldsen's "iconic spectacle" was "estranged . . . from the real suffering and misery of the historical Jesus." 44 Despite his attraction to the Exhibit's display of modernity, Cutler argues, Whitman tried to escape its dangerous tendency to dissolve the individual into a "totality" by insisting that the individual self is protected by its power to "see." But 
ultimately Whitman must have realized, according to Cutler, that this "ocular-centric" defense was itself a danger, threatening to turn the individual's world into a superficial image, leaving the viewer "gaping" at a mere "semblance," "haunted by the specter of alienation." 45 Relying on a selective reading of the important Crucifixion and Resurrection passage in "Song of Myself," 46 Cutler then attempts to connect this general threat of empty "gaping" to Whitman's particular fascination with Thorwaldsen's "massive nordic Christ," suggesting that Whitman must have felt that the historical reality of the Crucifixion was "erased before the gaping eye and falsely separate look of the exhibition goer." 47

It seems to me, however, that this argument misconstrues both Thorwaldsen's tableau and Whitman's attraction to it, obscuring the anecdote's clue to the emerging poetics of Leaves of Grass. Admittedly Thorwaldsen's still popular image of Christ is so banal that for someone to spend hours in front of it alone would indeed seem like pointless gaping. But that is not what the Crystal Palace story claims. On the contrary, it points to Whitman's interest in the whole group of statues, to that colossal congregation of ordinary men drawn together in the moment of electrifying realization that their crucified leader is (again) alive. ${ }^{48}$

In focusing on the isolated Christ as a mere "semblance," as an instance of the dangerous "spectacle" of the Exhibition, Cutler places Whitman, somewhat ironically, in the initial position of the disciples who were, as the Gospel of Luke puts it, "frightened, and supposed that they saw a spirit." 49 But the central theme of this famous scene is how Jesus overcomes his disciples' fear of specters by offering them his physical body as tangible evidence that what they now see really is the substantial, fleshly presence of the man they have just seen hanging from a cross. "Why are you troubled, and why do questionings rise in your hearts?" Jesus asks. And then he holds out his wounded hands: "See my hands and my feet, that it is I myself; handle me, and see; for a spirit has not flesh and bones as you see that I have." 50

It seems to me that Christ's challenging invitation to his disciples anticipates the distinctively incarnational poetics of the poem that would become "Song of Myself." Whitman's early Leaves would be distinguished from the more exclusively visual mode of Emerson by precisely this emphasis on "my hands and my feet," on "flesh and bones," on the substantial, bodily concreteness of the "I myself" as the key to a shared faith that reaches beyond death. In fact the words of Christ that Thorwaldsen's tableau embodies - "It is I myself; handle me, and see"could easily be taken to express the core of Whitman's revolution: his extraordinary way of presenting his own "I myself," his way of embodying the spirit in the flesh, of privileging touch as the foundation of a higher kind of seeing. 
Moreover the sense of a shared reality projected in this set of statues, a reality at once physical and spiritual and common to all, would also be fundamental to Whitman's new poetics. In a sense Thorwaldsen's scene is meant to represent the origin of the Christian community, as the discouraged and disintegrated band of disciples is drawn together and re-energized by Christ opening his hands for them to touch. Put another way, what seems to have been fascinating about Thorwaldsen's statues was not a matter of individual figures, certainly not the Christ taken alone, but the synergy of the whole group, the energetic field created among and around them as the disciples responded in their individual ways to Christ's gesture. That is why, I suspect, visitors felt they were "entering a sacred edifice," why men reverently removed their hats when they approached this quiet, curtained space in a side gallery of the noisy Crystal Palace. Surely Whitman would have noticed that effect as he stood there hour after hour. Surely he was studying not just the plaster figures but the singular reaction of his fellow Americans as they drew together and looked up in reverent awe. Within months his new poetry would emulate that uncanny effect, attempting to create an imaginative space in which ordinary people would be drawn together around a charismatic figure who overcomes individual doubt and social disintegration by celebrating the fleshy "I myself" that is shared equally by all.

Does that mean that Whitman tried to model Leaves on the Thorwaldsen display? Certainly not in a formal way, for his new poems would be open and moving and full of sounds, in deep contrast to the silent, static, enclosed space of "Christ and His Apostles." And yet the emerging poet may have learned something special here, something about the flesh and the spirit, about touch and sight, about the emergence of the transcendent in the midst of the ordinary, about the melding of many into one in response to the man/god who offered them the evidence of his own body. Recall what would become the opening words of his new poem:

I celebrate myself,

And what I assume you shall assume,

For every atom belonging to me as good belongs to you.

There is nothing explicitly about Christ in those famous lines. But I can imagine Whitman thinking them as he contemplated Thorwaldsen's extraordinary scene, thinking them as he watched the reverent crowds gather around the disciples drawn together by Christ's open hands. "For every atom belonging to me as good belongs to you"-Whitman's words could be as an antiphonal response to the words silently dramatized by Thorwaldsen's Christ: "It is I myself; handle me, and see." 51

The Crystal Palace police were there to prevent literal handling, of course. But some kinds of touching, some kinds of being touched, they 
could not see. Perhaps in the end the police were right to be suspicious. Perhaps Whitman did have strange designs on these huge statues. In some deeper dimension the poet may have evaded the police surveillance, taking away with him far more than they knew.

\section{Pacific Lutheran University}

\section{NOTES}

1 Ed Cutler, "Passage to Modernity: Leaves of Grass and the 1853 Crystal Palace Exhibition in New York," Walt Whitman Quarterly Review 16 (Fall 1998), 65-89.

2 Cutler, 71-72, 83-84.

3 Cutler, 83 and 71. See Emory Holloway, Whitman: An Interpretation in Narrative (New York: Alfred A. Knopf, 1926), 97. Though a diligent scholar, Holloway was at times quite unreliable, as in his embroidering the myth of Whitman's affair with a New Orleans woman.

\section{Cutler, 76.}

5 The inner facing pages of the fourth folded sheet (hereafter $4 \mathrm{~b}-\mathrm{c}$ ) of "Memoranda," William Douglas O'Connor's draft of a document sent to Moncure Conway in May 1866, now in The Yale Collection of American Literature, Beinecke Rare Book and Manuscript Library, Yale University; cited hereafter as "Memoranda." See Figure 1.

6 Emory Holloway and Ralph Adimari, eds., New York Dissected (New York: Rufus Rockwell Wilson, 1936); hereafter cited as NYD. Holloway quoted verbatim three sentences from two parts of O'Connor's "Memoranda": one about Whitman's familiarity with German philologists $(210 \mathrm{n} .8)$, the very next sentence about his reading only English (51), and a third about his frequenting the Egyptian Museum (27). Holloway cited an O'Connor manuscript written "to Moncure Conway in 1866," a document then "in the collection of Henry Goldsmith" but clearly the "Memoranda" now at Yale $(N Y D, 209$, n. 1).

7 NYD, 27 (my emphasis), referring to a sentence about the Egyptian Museum that immediately precedes the (cancelled) Crystal Palace story in the "Memoranda" (4b). Though the antecedent to "his own" is clearly "Whitman," Holloway may have intended merely to distinguish O'Connor's rough draft (the Goldsmith/Yale holograph) from the fair copy O'Connor sent to Conway (lost-except for one sheet: see note 11 below).

8 It is certain that Whitman did not write a "draft" of the whole of O'Connor's long "Memoranda," much of which seems to be O'Connor's version of what he heard from Whitman. O'Connor also melded various Whitman notes into his own distinctively personal communication to Conway, in one case explicitly quoting what he calls a Whitman "letter" and elsewhere copying fragmentary Whitman holographs that are still extant (see below, note 11).

9 The inner facing pages and back page of the fourth folded sheet. See the photograph on the back cover. For assistance in deciphering, I am indebted to Megan Benton and Barbara Temple-Thurston. 
10 This collaboration is the subject of my book-in-progress that pulls together O'Connor's "Memoranda," some of Burroughs's draft essays (now in the Berg Collection of the New York Public Library), and several Whitman manuscript notes that Grier failed to include in NUPM. A second book will include a critical facsimile edition of Whitman's multiple drafts of "Introduction" $(1861,1864)$ and "Inscription" (1865-66), most of which are now in the Oscar Lion Collection of the New York Public Library.

11 The 26-page Beinecke "Memoranda" is O'Connor's rough draft-seven sheets folded once, with four pages of text on each sheet except the last. It ends abruptly, probably because at that point O'Connor was merely copying a Whitman holograph. By a happy accident the conclusion of the fair copy that O'Connor actually sent Conway is now in the Spahr Library at Dickinson College (a single folded sheet, numbered " 8 ," with four pages of text). There is a small gap between the end of the Beinecke draft and the beginning of the Spahr fair copy, but we can deduce what was written there because the Whitman document that O'Connor was copying at that point is now in the Berg Collection of the New York Public Library. The only published description of this material, in Florence Bernstein Freedman's biography of O'Connor, is unreliable, though her partial transcripts are fairly accurate in themselves (William Douglas O'Connor: Walt Whitman's Chosen Knight [Athens, Ohio: Ohio University Press, 1985], 220-224). Jerome Loving alluded to the Beinecke "Memoranda" in two brief notes, without any description or discussion, in his Walt Whitman's Champion: William Douglas O'Connor (College Station, Texas: Texas A \& M University Press, 1978), 151 , note 3 ; and 153-154, note 6 . In a third note (155-156, note 8 ), Loving transcribed four distinct Whitman holographs that O'Connor used in his May 1866 "Memoranda"; but Loving mistakenly presented them as if they were a single document intended for the 1865 effort to protest Whitman's dismissal, and his transcriptions are not always reliable (e.g., "glorious" for "glowing," "at lust" for "at last").

12 "Memoranda," 2b.

13 "Memoranda," 4c-d.

14 "Memoranda," 4c.

15 The phrase is from O'Connor's letter to Conway, February 7, 1867, published in Randall H. Waldron, "Walt Whitman's British Connection: Letters of William Douglas O'Connor," The Papers of the Bibliographical Society of America 75 (1981), 293. Conway used much of what O'Connor had sent him in his "Walt Whitman," Fortnightly Review 6 (October 15, 1866), 538-548. But Conway also included his own colorful recollections about visiting the poet in the $1850 \mathrm{~s}$, and that led both Whitman and O'Connor to object to his fanciful romanticizing. In fact what he recalled was probably reliable, apart from his melding two visits into one. When O'Connor later wrote to Conway, in fact, he did not challenge any particular details, objecting only to Conway's emphasis on "Orientalism" as opposed to "modernness" and "Americanism" (December 5, 1866: Waldron 290-291) and to his general implication that Whitman was "eccentric" (February 7, 1867: Waldron 292). For Whitman's views on Conway, see Edwin Haviland Miller, ed., The Correspondence (New York: New York University Press, 1961), 1:294, 297; and Horace Traubel, With Walt Whitman in Camden (1912, rpt. New York: Rowan and Littlefield, 1961), 3:16-17. For O'Connor's views, in addition to Waldron see excerpts from letters to John Trowbridge and Ferdinand Freiligrath in Clara Barrus, Whitman and Burroughs, Comrades (Boston: Houghton Mifflin, 1931), 40. 
16 Edwin G. Burrows and Mike Wallace include a much abbreviated version, probably derived from Holloway, in their monumental Gotham: A History of New York City to 1898 (New York: Oxford University Press, 1999), 707: "Entranced by the Crystal Palace, he [Whitman] returned so often that officials assigned detectives to shadow the tall and roughly garbed man."

17 For background on the New York police I rely on Edward K. Spann, The New Metropolis: New York City, 1840-1857 (New York: Columbia University Press, 1981), 39, 54-55, 316-319, 324-326, and 368-400. See also Burrows and Wallace, Gotham, 635-638 and 835-841.

18 "A Police in Uniform," New York Times, June 24, 1853. See other letters and editorials on June 23 and 25.

19 New York Times, June 24, July 13 \& 14, August 6, 1853.

20 New York Times, July 13, 1853.

21 Spann, 325.

22 Spann, 369.

23 See the woodcut from Frank Leslie's Illustrated Newspaper, July 18, 1857, reproduced in Spann, 498, and in Gotham, 840.

24 August 23, 1856, in NYD, 140.

25 Ibid.

26 August 9, 1856, in NYD, 122.

27 July 12, 1856, in NYD, 81.

28 "The Civil War in New York" and "The Dead Rabbit Democracy," Brooklyn Daily Times, June 17 and July 8, 1857, in Emory Holloway and Vernolian Schwarz, eds., I Sit and Look Out (New York: Columbia University Press, 1932), 130-131 and 92-94, hereafter cited as ISLO. Jerome Loving has raised doubts about the authorship of these editorials by noting how slight the evidence is for the widely held belief that Whitman was this newspaper's editor in 1857-1859 (Walt Whitman: The Song of Himself [Berkeley: University of California Press, 1999], 227-229). In a 1857 notebook Whitman noted that the Mayor had ordered his Captains to "hold on to the Station Houses"; but this reveals nothing of what he felt about this state vs. city confrontation (NUPM, 1:272).

29 ISLO, 131.

30 ISLO, 130.

31 Whitman, "1862 Notebook," Harned Collection, Library of Congress, LC \#94, page [69]. Slashes indicate the short lines that Whitman inserted to separate lines of text. When Grier published this notebook (incipit title "Return My Book," NUPM $2: 478-524)$, he did not have access to this page because he had to rely on partial photostats and transcripts, the original notebook having been lost when the Library of Congress moved materials into storage during World War II. After the recovery of four such "lost" notebooks in 1995, the Library of Congress made digital copies available on its Web site, from which I transcribed this page. See "Poet at Work: Recovered Notebooks from the Thomas Biggs Harned Walt Whitman Collection" at <http://memory.loc.gov/ammem/wwhome.html>, image 69. In another volume of NUPM (1:467), Grier copied Charles I. Glicksberg's 1933 transcript of this page, 
treating it as a separate "lost" fragment unrelated to "Return My Book," the 1862 notebook in which it is page 69.

32 See "Song of Myself," line 160 ("The excited crowd, the policeman with his star quickly working his passage to the centre of the crowd") and line 280 ("The machinist rolls up his sleeves, the policeman travels his beat, the gate-keeper marks who pass"), and "First O Songs for a Prelude," line 38 ("The tumultuous escort, the ranks of policemen preceding, clearing the way"), in Harold W. Blodgett and Sculley Bradley, eds., Leaves of Grass: A Comprehensive Readers Edition (New York: New York University Press, 1965), 36, 42, and 281.

33 The policemen in the 1855-1862 notebooks include (with NUPM pages in parentheses) Bob Fraser (249), Jim (250), Jack (251), John Stoothoof (251, 481), Johny Williams (252), Charley Quail (253, 482), Jerry (253), Jake Beasly (253), Ab'm Litchalt (254), Wm Stewart (255), Tom (255), Thos Shephard (256), Patrick Corr (256), Pete Clayton (256), James Metcalf (454, 488), Jack Campbell (481), James Gillen (496), and Thomas Wright (498). From Washington years we find Patrick O'Hara (813), Wm Raines (815), John Davis (829), Wallace Loyd (845), and Geo S. McWatters (846). In 1870 Whitman gave McWatters, a New York policeman, an inscribed copy of Drum-Taps (NUPM, 2:846, note 37). He also defended Peter Doyle's brother Francis, a Washington policeman publicly criticized for arresting a young boy for theft; Whitman protested "this attempt to make martyrs and heroes of the steadily increasing swarms of juvenile thieves \& vagabonds who infest the streets of Washington" (NUPM, 2:783-784).

34 NUPM, 2:488, 543, 845. Grier notes that Tompkins was listed as a policeman in the New York City directory (NUPM, 2:488, note 96). The earliest of these entries is dated June 1862, but Whitman could have met him earlier. One might think Whitman would not remain friends with a deserter, but the third entry is in a notebook started in 1867.

35 David Margolis, letter to Paul DuBois, February 21, 1985, The College of New Jersey Library.

$36 \mathrm{Al}$ [fred] Woollacott to Oscar Hammerstein, April 16, 1956, The College of New Jersey Library (Trenton). “Thompkins" is Woollacott's spelling; Whitman's is "Tompkins."

37 Ibid.

38 Unfortunately Woollacott did not mention this first edition in his 1956 letter; he said he was passing on the Thompkins story because he had heard Hammerstein mention Whitman on a television program. Nevertheless he may have acquired his 1855 Leaves as a wedding present from Fern Thompkins, since he heard her Whitman story the year of his marriage and identified her as "a close neighbor" of his fiancée. The Woollacott/Hammerstein 1855 Leaves also contained a single-sheet Whitman holograph draft of the poem "Inscription" from 1866. Perhaps Whitman gave this to his friend Elijah; or perhaps the first edition and the manuscript leaf were assembled by Woollacott, or by Hammerstein, or by some earlier collector. I am grateful to Michael Robertson and Nelson Evans of the College of New Jersey for bringing these materials to my attention.

39 Cutler, 76, 65. Here is his more technical version of his thesis: "Progressive belief in the power of mass visual display for the improvement of America's laboring classes, along with a metaphysics of historical development and the relation of self to other and self to world, combine in Whitman's new poetics to create a discursive parallel to the ideals and representational strategies of the world exhibition" (66). 
40 "A World's Show," Good-Bye My Fancy (Floyd Stovall, ed., Prose Works 1892 [New York: New York University Press, 1963]), 2:681; hereafter cited as PW. This 1891 reminiscence emphasizes the "gallery of paintings" and the dispersed statuary, “among the rest, Thorwaldsen's 'Apostles,' colossal in size." It does conclude by mentioning "products and handiwork from the workers of all nations"; but "handiwork" is hardly a feature of "industrial modernity" (Cutler, 85). Whitman published two brief comments on the building itself (Brooklyn Daily Times, June 5, 1857 and October 6, 1858, ISLO, 129-130 and 147). He also left three slight manuscript references: in a 1854 note on the death of Bill Guess - "Was with me in the Crystal Palace . . . a thoughtless good fellow" (NUPM, 1:199); a recollection of the heat-"opened July 14. 1853-(I go for a year.) — the great heat August that year-400 deaths in three or four days in N Y from it" (NUPM, 3:1065); and a gloss on an 1857 clipping about how a list of patents "illustrates America ... (Remember the show at the Crystal Palace, and the American Institute fairs)" (Trent Collection, Duke University Library).

41 Cutler followed C. Carroll Hollis (who followed linguist Roman Jakobson) in reducing Whitman to a metonymic (vs. metaphoric) poet. I think this now common approach confuses a worldview ("kosmos") with a poetic trope (metonym), unfortunately deflecting attention from Whitman's distinctive use of metaphors and other traditional figures - synecdoche, irony, personification, apostrophe. See Cutler, 7781, and Hollis, Language and Style in Leaves of Grass (Baton Rouge: Louisiana State University Press, 1983), Chapter 5, "Metonymy in Whitman and Leaves of Grass." On the danger of such binary reductiveness, forcing a choice between metonym and metaphor, see Paul Ricoeur, The Rule of Metaphor (Toronto: University of Toronto Press, 1975), Study 6, "The Work of Resemblance."

42 New York Times, July 20, August 18 \& 19, 1853. According to Horace Greeley, the Thorwaldsen statues were "the most generally admired feature of the Exhibition" (Art and Industry as Represented at the Exhibition at the Crystal Palace, New York, 1853-54 [New York: Redfield, 1854], 61-62). These were full-size plaster models, originally installed in Copenhagen's cathedral while the marble statues were being finished in Italy. By 1853 they had become the property of the Danish consul in New York, who loaned them to the Exhibit and asked one of the Thorwaldsen sculptors to arrange their display (New York Times, July 1, 1853). For a general overview of the Crystal Palace Exhibition, see Charles Hirschfeld, "America on Exhibition: The New York Crystal Palace,” American Quarterly 9 (Summer 1957), 101-116.

43 New York Times, July 20, 1853.

44 Cutler, 83.

45 Cutler, 81-84 and passim.

46 See "Song of Myself" in its untitled 1855 version, pages 39-43 in a facsimile of the first edition of Leaves of Grass, or pages 64-71 in Justin Kaplan, ed., Walt Whitman: Complete Poetry and Collected Prose (New York: The Library of America, 1982). At the end of a series of vignettes in which the poet has projected himself into the painful bodily experiences of many who have suffered and died ("I do not ask the wounded person how he feels .... . I myself become the wounded person"), Whitman finds himself on "a verge of the usual mistake." That mistake is his "forgetting," in this crescendo of vicarious suffering, that the Crucifixion is prelude to Resurrection. In his looking "with a separate look on my own crucifixion," Whitman has failed to remember that all this pain and death is shaped by the larger pattern revealed in the Passion: that "the grave of rock multiplies what has been confided to it." When he does recall all this, suddenly "the corpses rise . . . . the gashes heal" and he "troop[s] forth replenished with supreme power, one of an average unending procession." Cutler turns this 
upside down. He argues that Whitman's "usual mistake" is not his sinking too exclusively into this vicarious suffering but "his failure . . . to be fully unified and sympathetic with the objects he contemplates." What Whitman now remembers, according to Cutler, is "his ultimate otherness," his "gaping" with a "separate look" that is "not commensurate to the experience of Christ's suffering"(83). Ignoring the Resurrection images, Cutler considers this a crisis of alienation in "Song of Myself," a crisis parallel to what Whitman must have felt as he confronted the Thorwaldsen "Christ," because that statue was "estranged as an iconic spectacle from the real suffering and misery of the historical Jesus"(83).

47 Cutler, 83-84.

48 O'Connor: "giant group of statuary" and "huge group of statuary" ("Memoranda" 4b \& 4c); Whitman: “Thorwaldsen's 'Apostles,' colossal in size” ( $P W, 2: 681)$; and Holloway: "Thorwaldsen's marbles" (Whitman, 1926, 97). Note that the New York Times reporter also emphasized the group (note 43 above).

49 Revised Standard Version, Luke 24:37.

50 Revised Standard Version, Luke 24:38-39.

51 For a contrasting view of the religious significance of these opening lines, see Michael D. Sowder, "Walt Whitman, The Apostle," Walt Whitman Quarterly Review 16 (Winter/Spring 1999), 207-210: “['I celebrate myself'] signals the difference between Whitman's new religion and Christianity. This voice does not cower guiltily hoping for a better world but celebrates a self and a world that is present-bodily, materially, now." 